\title{
Meningkatkan Aktivitas dan Prestasi Belajar Siswa Materi Pokok Danish Pastry dengan Menerapkan Model Pembelajaran Tutor Sebaya (Peer Tutoring)
}

\author{
Luh Sari*
}

SMK Negeri 2 Singraja

\begin{abstract}
Abstrak
Tujuan dari diadakannya penelitian ini adalah untuk meningkatkan aktivitas belajar dan prestasi belajar siswa pada materi pokok danish pastry di kelas XIA2 SMK Negeri 2 Singaraja, Tahun Pelajaran 2018/2019 melalui penerapan model pembelajaran tutor sebaya (peer tutoring). Penelitian ini adalah penelitian tindakan kelas (PTK). Subyek penelitian adalah peserta didik kelas XIA2 di SMK Negeri 2

Keywords:

model pembelajaran

Tutor Sebaya, aktivitas

belajar, prestasi

belajar siswa Singaraja yang berjumlah 36 orang peserta didik, 20 perempuan dan 16 orang siswa laki-laki. Sedangkan objek penelitian ini pada mata pelajaran produk pastry dan bakery pada materi pokok danish pastry dengan menggunakan medel pembelajaran tutor sebaya. Data aktivitas belajar siswa dikumpulkan dengan menggunakan lembar observasi aktivitas belajar siswa yang telah dipersiapkan, sedangkan data prestasi belajar siswa yaitu menggunakan tes. Analisis data yang digunakan pada penelitian ini menggunakan analisis data deskriptif. Berdasarkan analisis data yang dilakukan dapat disimpulkan bahwa implementasi model Tutor Sebaya dapat meningkatkan aktivitas dan prestasi belajar materi pokok Danish Pastry siswa kelas XI A2 SMK Negeri 2 Singaraja Tahun Pelajaran 2018/2019.
\end{abstract}

\section{PENDAHULUAN}

Pendidikan merupakan usaha sadar dan terencana untuk mewujudkan suasana belajar dan proses pembelajaran atau pelatihan agar peserta didik secara aktif dapat mengembangkan potensi dirinya secara terus menerus sepanjang hidup yang diharapkan dapat memiliki kekuatan spiritual keagamaan, emosional, pengendalian diri, kepribadian, kecerdasan, akhlak mulia, serta keterampilan yang diperlukan dirinya dan masyarakat. Pemerintah selalu berusaha untuk meningkatkan kualitas pendidikan dengan berbagai cara seperti mengganti kurikulum, meningkatkan kualitas guru melalui penataran-penataran, memberi dana Bantuan Operasional Sekolah (BOS) dan sebagainya. Pemerintah mengatur kebijakan pendidikan sesuai dengan fungsi dan tujuan Pendidikan Nasional dalam UU RI No. 20 tahun 2003 SISDIKNAS Bab II Pasal 3,yaitu:

Pendidikan nasional berfungsi mengembangkan kemampuan dan membentuk watak serta peradaban bangsa yang bermartabat dalam rangka mencerdaskan kehidupan bangsa, bertujuan untuk berkembangnya potensi peserta didik agar menjadi manusia yang bertakwa kepada Tuhan YME, berakhlak mulia, sehat, berilmu, cakap, kreatif, mandiri dan menjadi warga negara yang demokratis serta bertanggug jawab.

Menghayati isi dari UU No. 20 tahun 2003 tersebut, peneliti berpendapat bahwa tugas seorang pendidik memang berat, sebab kemajuan suatu bangsa ditentukan oleh keberhasilan pendidikan dari bangsa itu sendiri. Jika seorang guru atau pendidik tidak berhasil mengembangkan potensi peserta didik maka negara itu tidak akan maju, sebaliknya jika guru atau pendidik berhasil mengembangkan potensi peserta didik, maka terciptalah manusia yang cerdas, terampil, dan berkualitas. Menurut Wina Sanjaya (2006:19), peran guru adalah: "Sebagai sumber belajar, fasilitator, pengelola, demonstrator, pembimbing,

* Corresponding author. 
dan evaluator". Sebagai sumber belajar dan motivator guru harus mampu meningkatkan pemahanan dan membangkitkan motivasi siswa agar aktivitas proses pembelajaran berhasil dengan baik. Salah satu cara untuk meningkatkan pemahaman dan aktivitas siswa dalam proses pembelajaran adalah dengan mengganti model pembelajaran yang selama ini tidak diminati lagi oleh siswa, seperti pembelajaran yang dilakukan dengan ceramah dan tanya-jawab, model pembelajaran ini membuat siswa jenuh dan tidak kreatif. Suasana belajar mengajar yang diharapkan adalah menjadikan siswa sebagai subjek yang berupaya menggali sendiri, memecahkan sendiri masalah-masalah dari suatu konsep yang dipelajari, sedangkan guru lebih banyak bertindak sebagai motivator dan fasilitator. Situasi belajar yang diharapkan di sini adalah siswa yang lebih aktif.

Fenomena seperti diatas merupakan permasalahan yang perlu segera ditemukan alternatifalternatif pemecahannya. Salah satu upaya yang dapat dijadikan alternatif pemecahan masalah tersebut adalah dengan menerapkan pembelajaran yang meningkatkan aktivitas dan hasil belajar belajar siswa melalui "metode tutor sebaya (peer tutoring)" pada mata pelajaran produk pastry dan bakery yang merupakan salah satu mata pelajaran produktif yang ada di SMK pariwisata, program keahlian tata boga. Friani (2016) model pembelajaran tutor sebaya (peer tutoring) adalah orang - orang dari kelompok sosial yang sama yang bukan guru profesional menolong satu sama lain untuk belajar dan membelajarkan mereka sendiri dengan mengajar. Model pembelajaran tutor sebaya yaitu pembelajaran yang dilakukan oleh teman-temannya yang mempunyai usia hampir sebaya (Anggorowati, 2011). Putu (2013) juga mengemukakan pendapat yang sama bahwa tutor sebaya merupakan pembelajaran yang terdiri dari pasangan siswa yang belajar dan berpraktik secara bersama-sama dalam tugas.

Pada dasarnya Sekolah Menengah Kejuruan menciptakan peserta didik yang siap kerja, dalam upaya menyiapkan peserta didik yang handal dan memiliki kesiapan kerja, mereka dibekali dengan beberapa mata diklat yang dikelompokan menjadi 3 program yaitu program normatif, program adaptif, dan program produktif. Program produktif adalah kelompok mata diklat yang berfungsi membekali peserta didik agar memiliki kompetensi kerja sesuai Standar Kompetensi Kerja Nasional Indonesia (SKKNI). Oleh karena itu, dengan menggunakan metode pembelajaran tutor sebaya pada mata pelajaran produk pastry dan bakery, diharapkan peserta didik dapat lebih aktif dalam bertanya atau mengeluarkan pendapat, karena peserta didik tidak bertanya atau mengeluarkan pendapat langsung di dalam kelas, melainkan ke tutor dalam kelompoknya. Pada pembelajaran tutor sebaya ini, sebagian peserta didik diajak untuk menjadi tutor atau sumber belajar dan tempat bertanya bagi temannya, sehingga bimbingan secara individu kepada peserta didik akan menjadi lebih optimal.

Penelitian ini dikuatkan oleh penelitian sebelumnya yang dilakukan oleh nurmala (2016) yang menyatakan penerapan model pembelajaran tutor sebaya dapat meningkatkan hasil belajar siswa kelas $\mathrm{V}$ SDN 20 Tolitoli pada operasi hitung campuran bilangan bulat

Berdasarkan uraian tersebut penulis mencoba menerapkan salah satu metode pembelajaran, yaitu metode pembelajaran tutor sebaya untuk mengungkapkan apakah dengan model pembelajaran tutor sebaya dapat meningkatkan aktivitas dan prestasi belajar siswa dalam mata pelajaran produk pastry dan bakery. Dari latar belakang tersebut maka penulis dalam penelitian ini mengambil judul"Pen erapan Model Pembelajaran Tutor Sebaya untuk meningkatkan Aktivitas dan Prestasi Belajar Siswa pada Materi pokok danish pastry kelas XI A2 tahun pelajaran 2018 / 2019".

\section{METODE PENELITIAN}

Penelitian tindakan kelas ini dilaksanakan di SMK Negeri 2 Singaraja Lokasinya di Jalan Srikandi No. 9 Singaraja. Penelitian tindakan kelas ini kurang lebih dilaksanakan selama tiga (3) bulan dimulai sejak minggu ke tiga (3) bulan September sampai akhir bulan Nopember 2018.

Subyek yang dijadikan sumber data dalam penelitian tindakan kelas ini adalah siswa kelas XIA2 SMK Negeri 2 Singarja dengan jumlah siswa 36 orang terdiri dari 19 orang siswa perempuan dan 17 orang siswa laki-laki. Penelitian Mata Pelajaran produk pastry dan bakery pada materi pokok danish pastry dengan menggunakan medel pembelajaran tutor sebaya.

Sebagai sumber belajar dan motivator guru harus mampu meningkatkan pemahanan dan membangkitkan motivasi siswa agar aktivitas proses pembelajaran berhasil dengan baik. Salah satu cara untuk meningkatkan pemahaman dan aktivitas siswa dalam proses pembelajaran adalah dengan mengganti model pembelajaran yang selama ini tidak diminati lagi oleh siswa, seperti pembelajaran yang dilakukan dengan ceramah dan tanya-jawab, model pembelajaran ini membuat siswa jenuh dan tidak kreatif. Suasana belajar mengajar yang diharapkan adalah menjadikan siswa sebagai subjek yang berupaya menggali sendiri, memecahkan sendiri masalah-masalah dari suatu konsep yang dipelajari, 
sedangkan guru lebih banyak bertindak sebagai motivator dan fasilitator. Situasi belajar yang diharapkan di sini adalah siswa yang lebih aktif.

Fenomena seperti diatas merupakan permasalahan yang perlu segera ditemukan alternatifalternatif pemecahannya. Salah satu upaya yang dapat dijadikan alternatif pemecahan masalah tersebut adalah dengan menerapkan pembelajaran yang meningkatkan aktivitas dan hasil belajar belajar siswa melalui "metode tutor sebaya (peer tutoring)" pada mata pelajaran produk pastry dan bakery yang merupakan salah satu mata pelajaran produktif yang ada di SMK pariwisata, program keahlian tata boga. Pada dasarnya Sekolah Menengah Kejuruan menciptakan peserta didik yang siap kerja, dalam upaya menyiapkan peserta didik yang handal dan memiliki kesiapan kerja, mereka dibekali dengan beberapa mata diklat yang dikelompokan menjadi 3 program yaitu program normatif, program adaptif, dan program produktif. Program produktif adalah kelompok mata diklat yang berfungsi membekali peserta didik agar memiliki kompetensi kerja sesuai Standar Kompetensi Kerja Nasional Indonesia (SKKNI). Oleh karena itu, dengan menggunakan metode pembelajaran tutor sebaya pada mata pelajaran produk pastry dan bakery, diharapkan peserta didik dapat lebih aktif dalam bertanya atau mengeluarkan pendapat, karena peserta didik tidak bertanya atau mengeluarkan pendapat langsung di dalam kelas, melainkan ke tutor dalam kelompoknya. Pada pembelajaran tutor sebaya ini, sebagian peserta didik diajak untuk menjadi tutor atau sumber belajar dan tempat bertanya bagi temannya, sehingga bimbingan secara individu kepada peserta didik akan menjadi lebih optimal.

Berdasarkan uraian tersebut penulis mencoba menerapkan salah satu metode pembelajaran, yaitu metode pembelajaran tutor sebaya untuk mengungkapkan apakah dengan model pembelajaran tutor sebaya dapat meningkatkan aktivitas dan prestasi belajar siswa dalam mata pelajaran produk pastry dan bakery.

Penelitian ini akan dilaksanakan dalam 2 siklus pembelajaran . Dimana masing-masing siklus pembelajaran terdiri dari empat tahap tindakan yaitu tahap perencanaan tindakan, pelaksanaan tindakan, observasi tindakan, dan tahap refleksi. Hasil refleksi digunakan sebagai penyempurnaan-penyempurnaan tindakan untuk siklus berikutnya, sedangkan refleksi yang digunakan pada siklus terakhir digunakan untuk membuat suatu rekomendasi-rekomendasi dari hasil peneitian ini.

Observasi dilakukan oleh peneliti selama proses pembelajaran dengan penerapan model tutor sebaya untuk meningkatkan aktivitas belajar siswa materi danish pastry. Observasi dilakukan dengan menggunakan lembar observasi aktivitas belajar siswa yang telah dipersiapkan. Sedangkan untuk mengukur prestasi belajar dilakukan dengan pemberian tes kepada siswa terkait materi danish pastry yang telah disiapkan oleh peneliti pada akhir siklus. Setelah data aktivitas belajar dan prestasi belajar siswa terkumpul, selanjutnya dilakukan analisis data dengan menggunakan analisis deskriptif.

\section{ANALISIS DAN PEMBAHASAN}

Pada Pelaksanaan siklus I tidak terlihat adanya siswa yang bermain-main ataupun asyik mengerjakan pekerjaan yang lain, semuanya fokus dalam mengerjakan tugas masing-masing. Pada pelaksanaan kegiatan kerja kelompok tampak adanya siswa yang mengalami kesulitan dalam mengerjakan tugas dan untuk mengatasi kesulitannya tersebut mereka bertanya kepada ketua kelompok yang berperan sebagai tutor sebaya yang tugasnya membantu dan menjelaskan kesulitan yang dihadapi temannya. Namun ada pula siswa yang mengalami hambatan dalam mengerjakan tugas tersebut langsung bertanya kepada peneliti / guru pengajar.

Pada post tes yang diberikan setelah dikoreksi oleh peneliti didapatkan hasil sebagai berikut: dari 36 siswa yang ada, 6 siswa mendapatkan nilai kurang dari 80 yang artinya nilainya masih di bawah KKM atau belum tuntas, sedangkan 30 siswa telah mendapatkan nilai sesuai KKM atau telah tuntas.

Dengan melihat titik lemah yang terjadi pada siswa dalam materi pokok danish pastry , maka perlu diadakan penjelasan yang mendasar pada anak-anak yang mengalami hambatan dengan memanfaatkan teman yang telah memahami konsep danish pastry tersebut untuk menjelaskannya. Mendata siswa yang memiliki kemampuan lebih dan mampu untuk menyampaikan materi yang dikuasainya kepada temannya.

Perlu dibentuk kelompok-kelompok kecil yang terdiri dari 4-5 orang siswa. Untuk berkolaborasi dalam belajar dan dipimpin oleh siswa yang memiliki kemampuan lebih dan mampu menyampaikan materi yang dikuasainya.

Pada pelaksanaan siklus II ini tampak sekali bahwa siswa sangat antusias dalam mengerjakan tugas kelompok , semua siswa terlihat aktif bersama kelompoknya dalam menyelesaikan tugas yang diberikan oleh peneliti. Berdasarkan hasil evaluasi yang telah dilaksanakan dan dikoreksi didaptkan hasil yang sesuai dengan indikator pencapaian hasil yang diharapkan, karena dari 36 siswa kelas XIA2 seluruhnya 
siswa mampu mendapatkan nilai sesuai KKM atau tuntas dan bahkan banyak siswa yang mencapai nilai di atas KKM, sehingga prosentasi siswa yang telah tuntas adalah $100 \%$.

Dari hasil evaluasi yang telah diberikan ternyata seluruhnya siswa mampu mendapatkan nilai sesuai KKM atau tuntas dan bahkan banyak siswa yang mencapai nilai di atas KKM. Aktivitas belajar siswa secara keseluruhan telah sesuai dengan yang diharapkan oleh peneliti karena dalam mengerjakan soal latihan kelompok,siswa aktif berdiskusi bersama tutornya masing-masing.

Penelitian tindakan kelas ini telah dilakukan sesuai dengan tahapan pelaksanaannya, yaitu rencana tindakan, pelaksanaan tindakan, observasi, dan refleksi. Peningkatan aktivitas belajar siswa pada saat pembelajaran materi pokok danish pastry ditentukan dari 7 aspek yang terdapat dalam lembar observasi mengenai aktivitas belajar siswa. Dari total keseluruhan siswa yaitu sebanyak 36 orang pada siklus I dan siklus II di peroleh hasil sebagai berikut: 1) Peserta didik yang aktif mengajukan pertanyaan kepada tutornya dari 46,66\% meningkat menjadi 58.33\%, 2) Peserta didik yang aktif menanggapi pertanyaan dari $19.44 \%$ meningkat menjadi $52.77 \%$, 3) Peserta didik yang aktif menyampaikan pendapat di depan teman sebayanya dari 43.88\% meningkat menjadi $47.22 \%$, 4) Peserta didik yang aktif berdiskusi bersama teman satu kelompoknya dari 88.88\% meningkat menjadi $94.44 \%, 5$ ) Peserta didik yang aktif memperhatikan materi yang disampaikan oleh tutornya dari 63.88\% meningkat menjadi $77.77 \%$, 6) Peserta didik yang aktif menulis hal-hal yang penting pada materi yang telah disampaikan oleh tutor dari 52.77\% meningkat menjadi 91.66\%, dan 7) Peserta didik yang aktif melakukan tugas-tugas sesuai dengan yang diminta oleh tutor atau gurunya sebanyak $100 \%$ baik di siklus I maupun di siklus II.

1) Peserta didik yang aktif mengajukan pertanyaan kepada tutornya dari 46,66\% meningkat menjadi 58.33\%, 2) Peserta didik yang aktif menanggapi pertanyaan dari $19.44 \%$ meningkat menjadi $52.77 \%$, 3) Peserta didik yang aktif menyampaikan pendapat di depan teman sebayanya dari $43.88 \%$ meningkat menjadi $47.22 \%$, 4) Peserta didik yang aktif berdiskusi bersama teman satu kelompoknya dari 88.88\% meningkat menjadi 94.44\%, 5) Peserta didik yang aktif memperhatikan materi yang disampaikan oleh tutornya dari $63.88 \%$ meningkat menjadi $77.77 \%$, 6) Peserta didik yang aktif menulis hal-hal yang penting pada materi yang telah disampaikan oleh tutor dari 52.77\% meningkat menjadi 91.66\%, dan 7) Peserta didik yang aktif melakukan tugas-tugas sesuai dengan yang diminta oleh tutor atau gurunya sebanyak $100 \%$ baik di siklus I maupun di siklus II.

Data hasi belajar siswa menunjukkan bahwa prestasi belajar siswa terhadap pembelajaran materi pokok danish pastry meningkat menjadi sangat baik. Hal ini dapat dilihat dari hasil post test yang telalah dilaksanakan di siklus I dan siklus II, siswa yang sudah tuntas dalam belajar dari 30 orang menjadi 36 orang, siswa yang sudah tuntas dalam belajar meningkat menjadi 100\% yaitu sebanyak 36 orang. Dengan uraian sebagai berikut: peserta didik yang memperoleh predikat A+ dengan perolehan nilai 96-100 yang asalnya berjumlah 0 orang meningkat menjadi 3 orang, peserta didik yang memperoleh Predikat $A$ dengan perolehan nilai 90-95 yang asalnya berjumlah 0 orang meningkat menjadi 13 orang, peserta didik yang memperoleh predikat B+ dengan perolehan nilai 86-89 yang asalnya berjumlah 3 orang meningkat menjadi 11 orang, peserta didik yang memperoleh predikat B dengan prolehan nilai 80-85 yang asalnya 26 orang meningkat menjadi 11 orang dan tidak ada siswa yang belum tuntas dalam belajar .

Nilai rata - rata pada siklus I (81.41)dengan ketuntasan klasikal $83.33 \%$ meningkat menjadi (87.05) dengan ketuntasan klasikal 100\%. Jadi dengan menggunakan metode Tutor Sebaya (peer tutoring) nilai rata - rata siswa kelas XI A2 Semester ganjil SMK Negeri 2 Singaraja Tahun Pelajaran 2018/2019 meningkat 5.64 dengan peningkatan ketuntasan klasikal 16.67\% Dari hasil angket respon siswa terhadap penerapan model pembelajaran tutor sebaya dapat diketahui bahwa siswa di kelas XIA2 memiliki respon yang tinggi sebesar 64.

\section{KESIMPULAN}

Berdasarkan hasil penelitian yang telah dilaksanakan, maka dapat disimpulkan bahwa aktivitas belajar siswa dalam mata pelajaran produk pastry dan bakery materi pokok danish pastry menunjukkan kriteria sangat aktif yaitu mengajukan pertanyaan kepada tutor sebanyak $58.33 \%$, berdiskusi bersama teman satu kelompok sebanyak 94.44\%, memperhatikan materi yang disampaikan oleh tutor sebanyak $77,77 \%$, menulis hal-hal yang penting pada materi yang telah disampaikan oleh tutor sebanyak 91,66\%, melakukan tugas-tugas sesuai dengan yang diminta oleh tutor atau gurunya sebanyak 100\%.

Data hasil belajar siswa menunjukkan bahwa prestasi belajar siswa terhadap pembelajaran materi danish pastry meningkat menjadi sangat baik. Hal ini dapat dilihat dari hasil post test yang telalah dilaksanakan di siklus I dan siklus II, siswa yang sudah tuntas dalam belajar dari 30 orang menjadi 36 orang, siswa yang sudah tuntas dalam belajar meningkat menjadi $100 \%$ yaitu sebanyak 36 orang. Dengan uraian sebagai berikut: peserta didik yang memperoleh predikat A dengan perolehan nilai 96-100 yang asalnya berjumlah 0 orang meningkat menjadi 3 orang, peserta didik yang memperoleh Predikat A 
dengan perolehan nilai 90-95 yang asalnya berjumlah 0 orang meningkat menjadi 13 orang, peserta didik yang memperoleh predikat $\mathrm{B}+$ dengan perolehan nilai 86-89 yang asalnya berjumlah 3 orang meningkat menjadi 11 orang, peserta didik yang memperoleh predikat B dengan prolehan nilai 80-85 yang asalnya 27 orang menjadi 11 orang dan tidak ada siswa yang belum tuntas dalam belajar. Nilai rata - rata yang diperoleh pada siklus I ( 81.41) dengan ketuntasan klasikal $83.33 \%$, siklus II nilai rata - rata siswa meningkat menjadi 87.05 dengan ketuntasan klasikal 100\%. Jadi dengan menggunakan metode Tutor Sebaya (peer tutoring) ketuntasan klasikal memingkat $16.67 \%$.

Dari hasil angket respon siswa terhadap penerapan model pembelajaran tutor sebaya dapat diketahui bahwa siswa di kelas XI A2 memiliki respon yang tinggi sebesar 64.

\section{DAFTAR PUSTAKA}

Anggorowati, N.P., 2011. Penerapan Model Pembelajaran Tutor Sebaya Pada Mata Pelajaran Sosiologi. Komunitas: International Journal Of Indonesian Society And Culture, Vol. 3, No.1.

Daryanto.(2008). Evaluasi Pendidikan. Jakarta. Rineka Cipta.

Friani, S.A., Suharman, A. and Effendi, E., 2016. Penerapan Model Pembelajaran Tutor Sebaya (Peer Tutoring) Untuk Meningkatkan Hasil Belajar Kimia Siswa Di Kelas XI IPA SMA Srijaya Negara Palembang. Jurnal Penelitian Pendidikan Kimia: Kajian Hasil Penelitian Pendidikan Kimia, Vol. 3, No. 1, pp.97-106.

Indrianie, N.S., 2015. Penerapan model tutor sebaya pada mata pelajaran bahasa inggris reported speech terhadap hasil belajar peserta didik MAN Kota Probolinggo. Jurnal Kebijakan dan Pengembangan Pendidikan, Vol. 3, No. 1.

Ishartono, B., Ashadi, A. and Susilowati, E., 2014. Implementasi Model Pembelajaran Problem Solving Berbantuan Peer Tutoring Dilengkapi Hierarki Konsep Untuk Meningkatkan Kualitas Proses Dan Hasil Belajar Materi Stoikiometri Pada Siswa Kelas X IPA 6 Sman 1 Sukoharjo Tahun Pelajaran 2013/2014. Jurnal Pendidikan Kimia, 4(1), pp.10-19.

Niken Sholi. 2015. Penerapan Model Tutor Sebaya pada Mata Pelajaran Bahasa Inggris Reported Speech terhadap Hasil Belajar Peserta didik MAN Kota ProbolinggoJurnal Kebijakan dan Pengembangan Pendidikan. Vol 3 no 1.

Nurmala Nurmala, Sukayasa Sukayasa, Baharuddin Paloloang. 2016. Penerapan Model Pembelajaran Tutor Sebaya Untuk Meningkatkan Hasil Belajar Siswa Kelas V SDN 20 Toli-Toli Pada Operasi Hitung Campuran Bilangan Bulat. Jurnal Kreatif Tadulako Online Untad. Vol 4 No 9.

Putu, R., 2013. Pengaruh model pembelajaran kontekstual berbantuan tutor sebaya terhadap hasil belajar biologi ditinjau dari motivasi belajar. Jurnal Pendidikan dan Pembelajaran IPA Indonesia, Vol. 3, No.1.

Sanjaya, Wina. (2009). Strategi Pembelajaran Berorientasi Standar Proses Pendidikan. Jakarta: Kencana

Sanubari, F., Yamtinah, S. and Redjeki, T., 2014. Penerapan metode pembelajaran tutor teman sebaya dilengkapi dengan media interaktif flash untuk meningkatkan minat dan prestasi belajar siswa kelas XI IPA 1 SMA Negeri 1 Sukoharjo tahun pelajaran 2013/2014 pada materi larutan penyangga. Jurnal pendidikan kimia, Vol. 3, No. 4, pp.145-154.

Sardiman. (2007). Interaksi dan motivasi belajar mengajar.Bandung : Remaja

Rosdakarya.

Tim Penyususn. (2008).Kamus Bahasa Indonesia. Jakarta : Depdiknas.

Ulfah, M., 2012. Optimalisasi Hasil Belajar IPA tentang Sistem Gerak pada Manusia melalui Metode Diskusi dengan Tehnik Pembelajaran Tutor Sebaya. Jurnal Pendidikan Tindakan Kelas, Vol. 3, No.1. 